\title{
Chemical constituents and cytotoxic effect from the barks of Goniothalamus chinensis Merr. \& Chun. growing in Vietnam
}

\author{
Loi Vu Duc ${ }^{1 *}$, Tung Bui Thanh ${ }^{1}$, Hai Nguyen Thanh ${ }^{1}$, Vung Nguyen Tien ${ }^{2}$ \\ ${ }^{1}$ School of Medicine and Pharmacy, Viet nam National University, Hanoi, Vietnam. ${ }^{2}$ National Institute of Forensic Medicine, Hanoi, Vietnam.
}

\begin{tabular}{|c|c|}
\hline ARTICLE INFO & ABSTRACT \\
\hline Article history: & \multirow{11}{*}{ 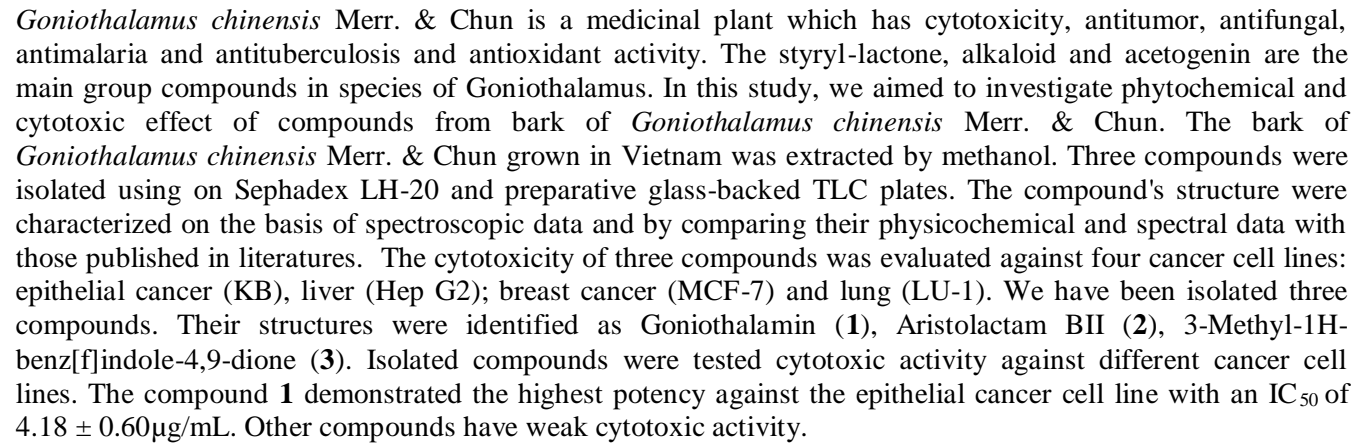 } \\
\hline Received on: 29/01/2016 & \\
\hline Revised on: 17/02/2016 & \\
\hline Accepted on: 09/03/2016 & \\
\hline Available online: $30 / 04 / 2016$ & \\
\hline Key words: & \\
\hline Goniothalamus chinensis & \\
\hline Merr. \& Chun, cytotoxicity, & \\
\hline & \\
\hline & \\
\hline & \\
\hline
\end{tabular}

\section{INTRODUCTION}

With the tropical climate, Vietnam has diversity of plant and animals species. In total, Vietnam has more than 12000 plant species; of which nearly 4000 species can be used in traditional medicine. The genus of Goniothalamus contains about 160 species in the world, mostly in Southeast Asia, among which about 19 are distributed in Vietnam (Wiart, 2007). Some species have been used as folk medicines for healing, for digestion and as a tonic plant. Main compounds in Goniothalamus are styryllactone, alkaloid and acetogenin which have cytotoxic, antitumor, insecticides, antifungal, antimalaria, antituberculosis and antioxidant activities (Blázquez et al., 1999). Orlikova et al., have showed goniothalamin, a styryl-lactone isolated from

\footnotetext{
* Corresponding Author

Loi Vu Duc, School of Medicine and Pharmacy, Vietnam National University, Hanoi, Floor 4 Building Y1, 144 Xuan Thuy, Cau Giay, Ha Noi, Vietnam. Email: ducloi.smpvnu[at]gmail.com
}

Goniothalamus macrophyllus, have cytotoxic and antiinflammatory effects. Thí compound also inhibits the tumor necrosis factor- $\alpha$-induced $N F-\kappa B$ activation and have antileukemic potential (Orlikova et al., 2013). Other study demonstrated that goniolactone $\mathrm{C}$, a styryl lactone, was extracted from Goniothalamus cheliensis, strongly inhibited platelet-derived growth factor-BB-induced vascular smooth muscle cell migration and proliferation (Sun et al., 2014). Goniothalamin, an active compound extracted from Goniothalamus griffithii, also inhibits human leukemic cells undergo apoptosis via intrinsic and extrinsic pathways (Petsophonsakul et al., 2013) and cervical cancer cells (HeLa) (Alabsi et al., 2012). Furthermore, goniothalamin also showed potent gastroprotective activity on gastric ulcers models in rats. The mechanism is goniothalamin may induce the production of sulfhydryl compounds and prostaglandins (Vendramini-Costa et al., 2014). For now, species of Goniothalamus continue being interested by many researches. However, there has been no report about the studies on the chemical constituents and bioactivity of this plant growing in Vietnam. 
Therefore a study about the chemical composition of Goniothalamus chinensis Merr. \& Chun is much needed. In this study, from barks of Goniothalamus chinensis Merr. \& Chun grown in Vietnam, have extracted, isolated and identified three compounds: Goniothalamin (1), Aristolactam BII (2),3-Methyl1H-benz[f]indole-4,9-dione (3). Furthermore, we have evaluated the cytotoxic of these compounds on four cell line epithelial cancer (KB), liver (Hep G2); breast cancer (MCF-7) and lung (LU-1).

\section{MATERIALS AND METHODS}

\section{Plant material}

Barks of Goniothalamus chinensis Merr. \& Chun. (Kingdom: Plantae; Phylum: Tracheophyta; Class: Magnoliopsida; Order: Magnoliales; Family: Annonaceae) were collected in $\mathrm{Ha}$ Giang province, Vietnam during 2013 and authenticated by the School of Medicine and Pharmacy, Vietnam National University, Hanoi, Vietnam (SMP-VNU). A voucher specimen (No. SMP2013-0018) has been deposited at the Herbarium of SMP-VNU.

\section{General experimental procedures}

Melting points were measured on Mikroskopheiztisch PHMK-50 (VEB WaegetechnikRapido, Germany). The FT-IR spectra were recorded on an IMPACT-410FT-IR spectrometer (CARL ZEISS JENA). The NMR $\left[{ }^{1} \mathrm{H}(500 \mathrm{MHz}),{ }^{13} \mathrm{C}(125 \mathrm{MHz})\right.$, and DEPT-90 and $135 \mathrm{MHz}$ )] spectra were recorded on an AVANCE spectrometer AV 500 (Brucker, Germany) in the Institute of Chemistry, Vietnam Academy of Science and Technology (VAST). Chemical shifts were reported in ppm downfield from TMS with $J$ in Hz. Electrospray Ionization Mass Spectra (ESI-MS) were recorded on a Varian Agilent 1100 LCMSD mass spectrometer. Analytical TLC was performed on Kieselgel $60 \mathrm{~F}_{254}$ (Merck) plates (silica gel, $0.25 \mathrm{~mm}$ layer thickness) and RP-18 $\mathrm{F}_{254}$ (Merck) plates (0.25 mm layer thickness). Spots were visualized using ultraviolet radiation (at 254 and $365 \mathrm{~nm}$ ) and by spraying with $10 \% \mathrm{H}_{2} \mathrm{SO}_{4}$, followed by heating with a heat gun. Column chromatography was performed on silica gel (70-230 and 230-400 mesh, Merck). Organic solvents were of analytical grade.

\section{Extraction and isolation}

Goniothalamus chinensis Merr. \& Chun barks of $1.7 \mathrm{~kg}$ was dried and extracted with methanol $(5 \mathrm{~L} \times 24$ hours $\times 3$ times $)$ at room temperature. The methanol extracts were combined and then evaporated to dryness in vacuo at $40^{\circ} \mathrm{C}$ to yield crude extract $(40.3 \mathrm{~g})$. This crude extract was chromatographed on Sephadex LH-20 column and eluted with gradient of $\mathrm{CH}_{2} \mathrm{Cl}_{2} / \mathrm{MeOH}$ to yield ten fractions F1-F10. Fraction F3 was further separated over a silica gel column and eluted with $n$-hexane/acetone (9:1) to yield eight subfractions F3.1-F3.8. Fraction 3.7 was further separated on Sephadex LH-20 column and eluted with $\mathrm{MeOH} / \mathrm{CH}_{2} \mathrm{Cl}_{2}(95 / 5)$ to yield two fractions F3.7.1 and F3.7.2. Fraction F3.7.2 was applied on preparative glass-backed TLC plates, coated with silica gel 60 and eluted with gradient of $n$-hexane/acetone to yield compound $\mathbf{1}$
(14 mg). Fraction 3.8 was further separated on Sephadex LH-20 column and eluted with $\mathrm{MeOH} / \mathrm{CH}_{2} \mathrm{Cl}_{2}(95 / 5)$ to yield compound 3 (17.5 mg). Fraction F4 was chromatographed over a silica gel column and eluted with $n$-hexane/acetone (9:1) to yield fifteen subfractions F4.1-F4.15. Fraction F4.13 was crystallized on solvents $\mathrm{CH}_{2} \mathrm{Cl}_{2}-\mathrm{MeOH}$ (1:1) to yield compound 2 (6.4mg).

Goniothalamin (1): was obtained as a light yellow, solid powder, melting point $82-84^{\circ} \mathrm{C} ; \mathrm{R}_{\mathrm{f}}=0,44$ (n-hexane$\left.\mathrm{CH}_{2} \mathrm{Cl}_{2} 20 / 80, \mathrm{v} / \mathrm{v}\right) ;[\alpha]_{\mathrm{D}}{ }^{27}=+81,0^{\circ}(\mathrm{C} 0,2 ; \mathrm{EtOH})$. FT-IR $(\mathrm{KBr}) v_{\max }\left(\mathrm{cm}^{-1}\right): 2925,1707,1664,1627,1454,1382$, $1244,1066,966,822,759,699,584,512,440$. UV $\lambda_{\max }$ $\mathrm{MeOH} \mathrm{nm} \mathrm{(log} \varepsilon): 210$ (4.43); 251 (4.32); 282 (3.25); 290 (3.03). (+)-ESI-MS: m/z $223[\mathrm{M}+\mathrm{Na}]+.{ }^{1} \mathrm{H}-\mathrm{NMR}$ $\left(500 \mathrm{MHz}, \mathrm{CDCl}_{3}\right): \delta$ (ppm) $7.40(2 \mathrm{H}, \mathrm{m}, \mathrm{H}-10, \mathrm{H}-14)$; 7.34 (2H, m, H-11, H-13); 7.27 (1H, m, H-12); $6.92(1 \mathrm{H}$, ddd, J=4.0; 5.0; 9.5 Hz, H-4); $6.73(1 \mathrm{H}, \mathrm{d}, \mathrm{J}=16.0 \mathrm{~Hz}, \mathrm{H}-$ $8) ; 6.27(1 \mathrm{H}, \mathrm{dd}, \mathrm{J}=6.5 ; 16.0 \mathrm{~Hz}, \mathrm{H}-7) ; 6.09(1 \mathrm{H}, \mathrm{dt}$, $\mathrm{J}=2.0 ; 10.0 \mathrm{~Hz}, \mathrm{H}-3) ; 5.10$ (1H, ddd, J=1.0; 6.5; $15.5 \mathrm{~Hz}$; $\mathrm{H}-6) ; 2,54$ (2H, m, H-5). ${ }^{13} \mathrm{C}-\mathrm{NMR}\left(125 \mathrm{MHz}, \mathrm{CDCl}_{3}\right): \delta$ (ppm) 163.8 (C-2); 144.5 (C-4); 135.8 (C-9); 133.1 (C8); 128.7 (C-11, C-13); 128.3 (C-12); 126.7 (C-10, C14'); 125.7(C-7); 121.7(C-3); 77.9 (C-6); 29.9 (C-5).

Aristolactam BII (2): was obtained as a yellow, crystalline powder, melting point $248-250^{\circ} \mathrm{C} ; \mathrm{R}_{\mathrm{f}}=0,38$ (n-hexane-acetone 67/33, v/v). FT-IR (KBr) $v_{\max }\left(\mathrm{cm}^{-1}\right)$ : 3449, 3194, 2926, 2855, 1717, 1644, 1607, 1462, 1379, $1031,838,720,624,530,466$. UV $\lambda_{\max } \mathrm{MeOH} \mathrm{nm}(\log$ ع): 205 (3.59); 232 (3.56); 263 (3.49); 276 (3.54); 286 (3.53); 317 (2.97); 385 (2.94). (+)-ESI-MS: m/z 302 $[\mathrm{M}+\mathrm{Na}]+; 581[2 \mathrm{M}+\mathrm{Na}]+.{ }^{1} \mathrm{H}-\mathrm{NMR}\left(500 \mathrm{MHz}, \mathrm{CDCl}_{3}\right.$ + $\left.\mathrm{CD}_{3} \mathrm{OD}\right): \delta(\mathrm{ppm}) 9.12(1 \mathrm{H}, \mathrm{m}, \mathrm{H}-5) ; 7.72(1 \mathrm{H}, \mathrm{s}, \mathrm{H}-2)$; $7.72(1 \mathrm{H}, \mathrm{m}, \mathrm{H}-8) ; 7.47$ (2H, m, H-6, H-7); 7.00 (1H, s, $\mathrm{H}-9)$; $4.02\left(3 \mathrm{H}, \mathrm{s}, 4-\mathrm{OCH}_{3}\right) ; 3.98\left(3 \mathrm{H}, \mathrm{s}, 3-\mathrm{OCH}_{3}\right) .{ }^{13} \mathrm{C}-$ NMR $\left(125 \mathrm{MHz}, \mathrm{CDCl}_{3}+\mathrm{CD}_{3} \mathrm{OD}\right): \delta(\mathrm{ppm}) 170.2$ $(\mathrm{C}=\mathrm{O}) ; 154.4$ (C-3); 151.5 (C-4), 134.8 (C-8a), 134.2 (C10), 128.9 (C-8), 127.4 (C-5), 127.4 (C-7), 126.9 (C-5a), 125.8 (C-6), 124.2 (C-10a), 121.2 (C-1), 120.8 (C-4a), 109.5 (C-2), 106.2 (C-9), $60.2\left(4-\mathrm{OCH}_{3}\right), 56.8\left(3-\mathrm{OCH}_{3}\right)$.

3-Methyl-1H-benz[f]indole-4,9-dione (3): was obtained as a yellow, solid powder, melting point $248-249^{\circ} \mathrm{C} ; \mathrm{R}_{\mathrm{f}}=$ 0,44 (n-hexane- $\mathrm{CH}_{2} \mathrm{Cl}_{2}$ 25/75, v/v). (+)-ESI-MS: m/z $210[\mathrm{MH}]^{+},(+)-\mathrm{ESI}-\mathrm{MS}: \mathrm{m} / \mathrm{z} 212[\mathrm{M}+\mathrm{H}]+;(+)-H R-E S I-$ MS m/z 212,0710 [M+H]+, FT-IR (KBr) $v_{\max }\left(\mathrm{cm}^{-1}\right)$ : 3429, 3322, 2938, 1647, 1588, 1507, 1403, 1238, 1031, 932, 714. UV (MeOH) $\lambda_{\max } \mathrm{nm}(\log \varepsilon): 258(4,07) ; 330$ $(3,32) .{ }^{1} \mathrm{H}-\mathrm{NMR}\left(500 \mathrm{MHz}, \mathrm{CDCl}_{3}+\mathrm{CD}_{3} \mathrm{OD}\right): \delta(\mathrm{ppm})$ $8.08(1 \mathrm{H}, \mathrm{m}, \mathrm{H}-5) ; 8.01(1 \mathrm{H}, \mathrm{m}, \mathrm{H}-8) ; 7.59$ (2H, m, H-6, $\mathrm{H}-7) ; 6.83$ (1H, m, H-2); 2.34 (3H, s, $\left.\mathrm{CH}_{3}-10\right) .{ }^{1} \mathrm{H}-\mathrm{NMR}$ (500 MHz, DMSO): $\delta$ (ppm) 12.65 (1H, br s, H-1); 8.18 (2H, m, H-5, H-8); 7.76 (2H, m, H-6, H-7); $7.13(1 \mathrm{H}, \mathrm{m}$, $\mathrm{H}-2) ; 2.31$ (3H, s, $\left.\mathrm{CH}_{3}-10\right) .{ }^{13} \mathrm{C}-\mathrm{NMR}\left(125 \mathrm{MHz}, \mathrm{CDCl}_{3}\right.$ 
+ $\left.\mathrm{CD}_{3} \mathrm{OD}\right): \delta(\mathrm{ppm}) 182.3(\mathrm{C}-9) ; 175.7(\mathrm{C}-4) ; 134.5(\mathrm{C}-$ 8a); 133.4 (C-4a); 133.2 (C-6, C-7); 132.7 (C-9a); 126.5 (C-5); 126.0 (C-8); 125.5 (C-2); 125.1 (C-3a); 122.8 (C3); $11.0\left(\mathrm{CH}_{3}-10\right)$.

\section{Cytotoxicity Assay}

Cytotoxicity of these compounds was evaluated against four types of cancer cell lines: epithelial cancer (KB), liver (Hep G2); breast cancer (MCF-7) and lung (LU-1) by 3-(4,5dimethylthiazol-2-yl)-2,5-diphenyltetrazolium bromide (MTT) assay. Cell lines were cultured in Dulbecco's Modified Eagle medium (DMEM) with $10 \%$ foetal bovine serum, at $37^{\circ} \mathrm{C}, 5 \%$ $\mathrm{CO} 2$ and $95 \%$ humidity. Cells were plated in 96-well flat bottom tissue culture plates and allowed to density of approximately $3 \times 10^{4} / \mathrm{mL}$ then begin experiment. The cells were incubated with $100 \mu \mathrm{L}$ of compound at a range of concentration (from $1 \mu \mathrm{g} / \mathrm{mL}$ to $1000 \mu \mathrm{g} / \mathrm{mL}$ ) for 72 hours. Then, $0.2 \mathrm{mg} / \mathrm{mL}$ MTT reagent was added to each well, and the plate was incubated for 4 hours at $37^{\circ} \mathrm{C}$. Next, DMSO (100 uL) was added and the plates shaken for $5 \mathrm{~min}$. The absorbance for each well was measured at $540 \mathrm{~nm}$ in a microtiter plate reader and the percentage cell viability (CV) was calculated manually using the formula:

$$
\mathrm{CV}=\frac{\text { Average abs of duplicate drug wells }}{\text { Average abs of control wells }} \times 100
$$

The effects of compounds were expressed by $\mathrm{IC}_{50}$ values (the drug concentration reducing the absorbance of treated cells by $50 \%$ with respect to untreated cells) (Monks et al., 1991).

\section{RESULTS AND DISCUSSION}

\section{Isolation and Chemistry \\ Goniothalamin(1)}

Goniothalamin (1) was obtained as a light yellow, solid powder, melting point $82-84^{\circ} \mathrm{C}$ and the optical rotation $[\alpha]_{\mathrm{D}}{ }^{27}=+$ $81,0^{\circ}$ (c 0,$\left.2 ; \mathrm{EtOH}\right)$. The ring $\gamma$-lactone $\alpha, \beta$-unsaturated showed typical absorption bands arising from carbonyl group $\left(1707 \mathrm{~cm}^{-1}\right)$ inIR spectrum, maximum absorption wavelength at $\lambda_{\max } 210 \mathrm{~nm}$ $(\log \varepsilon$ 4,43; $\mathrm{MeOH})$ in UV spectrum and $\delta_{\mathrm{C}} 163,8$ in ${ }^{13} \mathrm{C}-\mathrm{NMR}$ spectrum. The molecular formula was established as $\mathrm{C}_{13} \mathrm{H}_{12} \mathrm{O}_{2}$ based on a molecular ion peak atm/z $223[\mathrm{M}+\mathrm{Na}]^{+}$. The ${ }^{1} \mathrm{H}-\mathrm{NMR}$ spectrum showed the presence of phenyl group with five signals proton at $\delta_{\mathrm{H}} 7,27-7,40\left(5 \mathrm{H}, \mathrm{m}, \mathrm{C}_{6} \mathrm{H}_{5}\right)$, signals of 4 proton olefinic at $\delta_{\mathrm{H}} 6,92(1 \mathrm{H}, \mathrm{ddd}, \mathrm{J}=4.0 ; 5.0 ; 9.5 \mathrm{~Hz}, \mathrm{H}-4) ; 6,73(1 \mathrm{H}, \mathrm{d}, \mathrm{J}=16,0$ $\mathrm{Hz}, \mathrm{H}-8) ; 6,27$ (1H, dd, J=6,5; 16,0 Hz, H-7); 6,09 (1H, dt, J=2,0; $10,0 \mathrm{~Hz}, \mathrm{H}-3)$. The ${ }^{1} \mathrm{H}-\mathrm{NMR}$ spectrum of compound $\mathbf{1}$ also exhibited the presence of a methylen signal at $\delta_{\mathrm{H}} 2,54(\mathrm{~m}, 2 \mathrm{H}, \mathrm{H}-$ $5)$ and a methinoxy signal at $\delta_{\mathrm{H}} 5,10(1 \mathrm{H}$, ddd, $\mathrm{J}=1.0 ; 6.5 ; 15.5 \mathrm{~Hz}$; $\mathrm{H}-6)$. The ${ }^{13} \mathrm{C}-\mathrm{NMR}$ and DEPT spectra of compound $\mathbf{1}$ indicated the presence of 13 carbon atoms in the molecule. There are a carbonyl carbon $\left(\delta_{\mathrm{C}} 163.8\right)$, one $\mathrm{CH}_{2}$ group at $\delta_{\mathrm{C}} 29.9$, one $\mathrm{sp}^{3}$ methine oxygenated carbons at $\delta_{\mathrm{C}} 77.9$; nine methine $\mathrm{sp}^{2}$ group at $\delta_{\mathrm{C}}$ 121.7-144.5 and one quaternary carbon $\mathrm{sp}^{3}$ at $\delta_{\mathrm{C}}$ 135.8. The signal in COSY spectra allowed correlating from C-3 to C-8. The coupling constants $\mathrm{J}(16.0 \mathrm{~Hz})$ between $\mathrm{H}-7$ and $\mathrm{H}-8$ indicated that two protons are in trans position. The coupling constants $\mathbf{J}$ (9.5 $\mathrm{Hz}$ ) between $\mathrm{H}-3$ and H-4 indicated that two protons are in cis position. Based on the above evidence and the literature data (Wattanapiromsakul et al., 2005)compound $\mathbf{1}$ was identified as goniothalamin. This compound is styryl lactone has been isolated from many Goniothalamus species. It has antitumor activity in vitro and in vivo (de Fátima et al., 2005; Mereyala and Joe, 2001; Tian et al., 2006). Furthermore, it has antifungal (Fatima et al., 2008) and antioxidant activity (Kim et al., 2012).

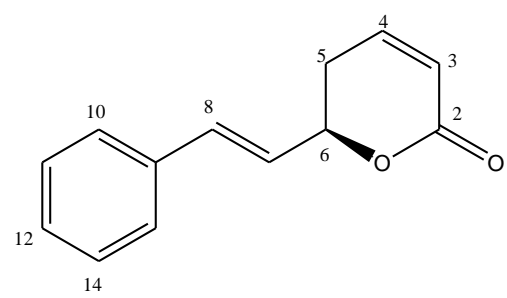

Fig. 1: Structures of compound 1.

\section{Aristolactam BII (2)}

Compound 2 was obtained as a yellow, crystalline powder, melting point $248-250^{\circ} \mathrm{C}$, gave positive result with Dragendorff agent. The IR spectrum showed typical absorption bands arising from $\mathrm{NH}\left(v_{\max } 3449 \mathrm{~cm}^{-1}\right)$ and $\mathrm{C}=\mathrm{O}\left(v_{\max } 1717 \mathrm{~cm}^{-1}\right)$. The UV spectrum in solvent $\mathrm{MeOH}$ showed typical maximum absorption wavelength of phenanthrene structure at $\lambda_{\max } \mathrm{nm}(\log \varepsilon)$ : 232 (3.56), 263 (3.49), 276 (3.54), 286 (3.53), 317 (2.97) and 385 (2.94). The molecular formula was established as $\mathrm{C}_{17} \mathrm{H}_{13} \mathrm{NO}_{3}$ based on a molecular ion peak at $m / z, 302[\mathrm{M}+\mathrm{Na}]^{+}$. The ${ }^{13} \mathrm{C}-\mathrm{NMR}$ spectra of compound 2 indicated the presence of 17 carbon atoms in the molecule. There are a carbonyl carbon $\left(\delta_{\mathrm{C}} 170.2\right)$, two methoxy groups $\left(\delta_{\mathrm{C}} 60.2\right.$ and 56.8), six methine $\mathrm{sp}^{2}$ group at $\delta_{\mathrm{C}}$ $106.2 ; 109.5 ; 125.8 ; 127.4 ; 127.4 ; 128.9$ and eight quaternary carbon $\mathrm{sp}^{3}$.

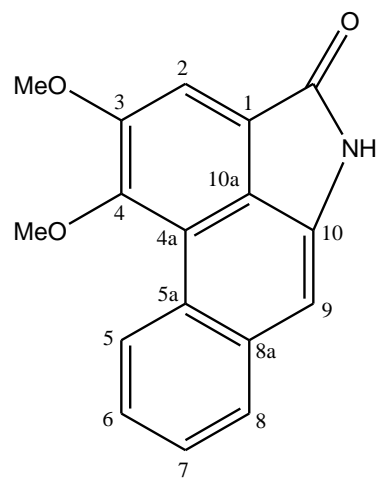

Fig. 2: Structures of compound Aristolactam BII (2);

The ${ }^{1} \mathrm{H}-\mathrm{NMR}$ spectrum of compound 2 exhibited the presence of 6 signals proton of aromatic ring at $\delta_{\mathrm{H}} 9.12(1 \mathrm{H}, \mathrm{m}, \mathrm{H}$ 5); 7.72 (1H, s, H-2); 7.72 (1H, m, H-8); 7.47 (2H, m, H-6 + H-7); $7.00(1 \mathrm{H}, \mathrm{s}, \mathrm{H}-9)$ and two methoxy groups $\mathrm{OCH}_{3}$ at $\delta_{\mathrm{H}} 4.02(3 \mathrm{H}, \mathrm{s}$, $\left.\mathrm{OCH}_{3}\right) ; 3.98\left(3 \mathrm{H}, \mathrm{s}, \mathrm{OCH}_{3}\right)$. HMBC spectrum showed the correlation between H-9 with C-8, C-5a, C-8a, C-10a and C-10; 
between $\mathrm{H}-5$ with $\mathrm{C}-7, \mathrm{C}-8 \mathrm{a}$ and $\mathrm{C}-5 \mathrm{a}$, between $\mathrm{H}-8$ with $\mathrm{C}-6, \mathrm{C}-$ 7, C-5a and C-9. Then it can deduced the correlation between $\mathrm{C}-8$ with C-8a, C-9, C-10 and C-10a; C-5 with C-5a, C-8a and C7.There is also the correlation between $\mathrm{H}-2$ with $\mathrm{C}-3, \mathrm{C}-4, \mathrm{C}=\mathrm{O}$ and $\mathrm{C}-1$, hence $\mathrm{C}-2$ correlates with $\mathrm{C}=\mathrm{O}$ through $\mathrm{C}-1$. The correlation between protons of methoxy group $\left(\delta_{\mathrm{H}} 4.02\right)$ with $\mathrm{C}-3$ $\left(\delta_{\mathrm{C}} 154.4\right)$ and protons of methoxy group $\left(\delta_{\mathrm{H}} 3.98\right)$ with $\mathrm{C}-4\left(\delta_{\mathrm{C}}\right.$ 151.5) indicated that two methoxy $\mathrm{OCH}_{3}$ group linked with carbon $\mathrm{C}-3$ and C-4. Based on the above evidence and the literature data(Marques et al., 2011) compound 2 was identified as Aristolactam BII. This compound has neuroprotective (Kim et al., 2004) and cytotoxicity with P-388 leukemia and A-549 lung adenocarcinoma epithelial cell line (Tsai et al., 2005).

\section{3-Methyl-1H-benz[f]indole-4,9-dione (3)}

Compound $\mathbf{3}$ was obtained as a yellow, solid powder. The molecular formula was established as $\mathrm{C}_{13} \mathrm{H}_{9} \mathrm{O}_{2} \mathrm{~N}$ based on a molecular ion peak at $m / z$ 212,0710 $[\mathrm{M}+\mathrm{H}]^{+}$. The IR spectrum showed typical absorption bands arising from $\mathrm{NH}\left(v_{\max } 3429 \mathrm{~cm}^{-1}\right)$ and carbonyl $\mathrm{C}=\mathrm{O}\left(v_{\max } 1647 \mathrm{~cm}^{-1}\right)$.

The ${ }^{1} \mathrm{H}-\mathrm{NMR}$ spectrum of compound $\mathbf{3}$ exhibited the presence of 5 signals proton of aromatic ring at $\delta_{\mathrm{H}} 8.08(1 \mathrm{H}, \mathrm{m}, \mathrm{H}-$ 5); 8.01 (1H, m, H-8), 7.59 (2H, m, H-6 and $\mathrm{H}-7)$ and $6.83(1 \mathrm{H}, \mathrm{m}$, $\mathrm{H}-2)$; and 1 methyl group at $\delta_{\mathrm{H}} 2.31(3 \mathrm{H}, \mathrm{s})$. The ${ }^{1} \mathrm{H}-\mathrm{NMR}$ spectrum of compound $\mathbf{3}$ also exhibited the presence of a proton $\mathrm{NH}$ signal at $\delta_{\mathrm{H}} 12.65\left(1 \mathrm{H}\right.$, br s, H-1). The ${ }^{13} \mathrm{C}-\mathrm{NMR}$ spectra of compound 3 indicated the presence of 13 carbon atoms in the molecule. There are a methyl group; 5 methine $\mathrm{sp}^{2}$ groups; and 2 carbonyls group at $\delta_{\mathrm{C}} 182.3(\mathrm{C}-9)$ và $175.7(\mathrm{C}-4)$ and 5 quaternary carbons in aromatic ring at $\delta_{\mathrm{C}} 122.8$ (C-3), 125.1 (C-3a), 133.4 (C4a), 134.5 (C-8a) and 132.7 (C-9a).

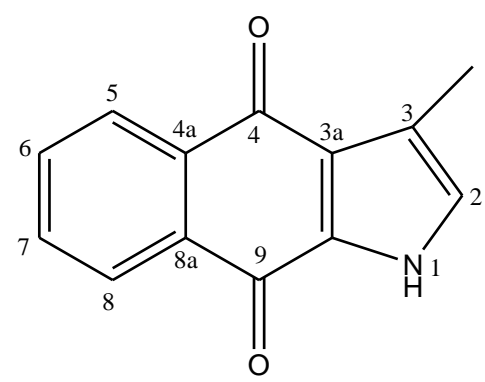

Fig. 3: Structures of compound 3-Methyl-1H-benz[f]indole-4,9-dione (3).

The signal in COSY spectra allowed determining the correlation from $\mathrm{H}-3$ to $\mathrm{H}-8$. HMBC spectrum showed the correlation between $\mathrm{H}-5$ and $\mathrm{H}-8$ with $\mathrm{C}-4 \mathrm{a}$ and $\mathrm{C}-8 \mathrm{a}$, confirmed the presence of benzene $\mathrm{A}$ ring. Also there are correlations between 2 carbonyls $\mathrm{C}-4$ and $\mathrm{C}-9$ with $\mathrm{H}-5$ and $\mathrm{H}-8$ in HMBC spectrum respectively. It allowed confirming the $\mathrm{C}-4$ and $\mathrm{C}-9$ linked to ring $\mathrm{A}$ at position $\mathrm{C}-4 \mathrm{a}$ and $\mathrm{C}-8 \mathrm{a}$. The pyrole $\mathrm{C}$ ring also is determined by HMBC spectrum: $\mathrm{H}-2$ correlates with $\mathrm{C}-3, \mathrm{C}-3 \mathrm{a}$ and $\mathrm{C}-9 \mathrm{a} ; \mathrm{CH}_{3}-10$ correlates with $\mathrm{C}-2$ and $\mathrm{C}-3 \mathrm{a}$. The methyl group position at $\mathrm{C}-3$ in pyrole $\mathrm{C}$ ring is also confirmed by NOE correlation between $\mathrm{H}-2$ and $\mathrm{CH}_{3}-10$. Based on the above evidence and the literature data (Efdi et al., 2010) compound 3 was identified as 3-methyl-1H-benz[f]indole-4,9-dione. This compound was first isolated from Goniothalamustapis Miq (Efdi et al., 2010).

\section{Bioactivity}

The result of cytotoxicity tests of isolated compounds against epithelial cancer (KB), liver (Hep G2), breast cancer (MCF-7) and lung (LU-1) cell lines are shown in Table 1.

Table 1: Cytotoxicity of isolated compounds

\begin{tabular}{lllll}
\hline \multirow{2}{*}{ Compounds } & \multicolumn{4}{c}{ IC $_{\mathbf{5 0}}(\boldsymbol{\mu g} / \mathbf{m L})$} \\
\cline { 2 - 5 } & \multicolumn{1}{c}{ KB } & \multicolumn{1}{c}{ HepG2 } & \multicolumn{1}{c}{ LU-1 } & \multicolumn{1}{c}{ MCF7 } \\
\hline Compound 1 & $4.18 \pm 0.60$ & $8.62 \pm 1.24$ & $8.04 \pm 1.18$ & $13.31 \pm 1.45$ \\
Compound 2 & $52.32 \pm 5.21$ & $85.29 \pm 3.47$ & $98.34 \pm 6.13$ & $134.87 \pm 7.97$ \\
Compound 3 & $67.32 \pm 3.73$ & $94.53 \pm 5.32$ & $105.43 \pm 2.41$ & $167.89 \pm 3.54$ \\
\hline
\end{tabular}

Only compound $\mathbf{1}$ exhibited strong cytotoxic activity against epithelial cancer (KB), liver (Hep G2), breast cancer (MCF-7) and lung (LU-1) cell lines. Previous study have demonstrated Goniothalamin possess anticancer potential activity through mechanism of induces apoptosis and inhibits TNF- $\alpha$-induced NF$\kappa \mathrm{B}$ activation (Orlikova et al., 2013; Seyed et al., 2014). For the compounds 2,3 , we have found the $\mathrm{IC}_{50}$ against fours tested cancer cell line were greater over than ten times as compared with compound $\mathbf{1}$.

\section{CONCLUSION}

From the bark of Goniothalamus chinensis Merr. \& Chun. we have isolated three compounds, Goniothalamin (1), Aristolactam BII (2), 3-Methyl-1H-benz[f]indole-4,9-dione (3). The compound 1 showed the highest potency against the epithelial cancer $(\mathrm{KB})$ cell line with an $\mathrm{IC}_{50}$ of $4.18 \pm 0.60 \mu \mathrm{g} / \mathrm{mL}$. Others compounds have weak cytotoxic activity against all cell lines tested.

\section{CONFLICT OF INTERESTS}

The authors declare that there is no conflict of interest regarding the publication of this paper.

\section{REFERENCES}

Alabsi, A.M., Ali, R., Ali, A.M., Al-Dubai, S.A., Harun, H., Abu Kasim, N.H., Alsalahi, A.. Apoptosis induction, cell cycle arrest and in vitro anticancer activity of gonothalamin in a cancer cell lines. Asian Pacific journal of cancer prevention : APJCP, 2012; 13: 5131-5136.

Blázquez, M.A., Bermejo, A., Zafra-Polo, M.C., Cortes, D. Styryl-lactones from Goniothalamus species-A review. Phytochemical Analysis, 1999; 10: 161-170.

de Fátima, Â., Kohn, L.K., Antônio, M.A., de Carvalho, J.E., Pilli, R.A. (R)-Goniothalamin: total syntheses and cytotoxic activity against cancer cell lines. Bioorganic \& medicinal chemistry, 2005; 13: 2927-2933.

Efdi, M., Fujita, S., Inuzuka, T., Koketsu, M. Chemical studies on Goniothalamus tapis Miq. Natural product research, 2010; 24: 657-662.

Fatima, A.d., Martins, C.V.B., de Resende, M.A., Ferreira Magalhaes, T.F., Lima, S., Henrique, B., Watanabe, G.A., Gois Ruiz, 
A.L., de Carvalho, J.E., Pilli, R.A. Antifungal activity of goniothalamin enantiomers. Letters in Drug Design \& Discovery, 2008; 5: 74-78.

Kim, R., Bihud, V., bin Mohamad, K., Leong, K., bin Mohamad, J., bin Ahmad, F., Hazni, H., Kasim, N., Halim, S., Awang, K.. Cytotoxic and Antioxidant Compoundsfrom the Stem Bark of Goniothalamus tapisoides Mat Salleh. Molecules, 2012; 18: 128.

Kim, S.R., Sung, S.H., Kang, S.Y., Koo, K.A., Kim, S.H., Ma, C.J., Lee, H.-S., Park, M.J., Kim, Y.C. Aristolactam BII of Saururus chinensis attenuates glutamate-induced neurotoxicity in rat cortical cultures probably by inhibiting nitric oxide production. Planta medica, 2004; 70, 391-396.

Marques, A.M., Velozo, L., de Moreira, D., Guimaraes, E.F., Kaplan, M. Aristolactams from roots of Ottonia anisum (Piperaceae). Natural product communications, 2011; 6: 939-942.

Mereyala, H., Joe, M. Cytotoxic activity of styryl lactones and their derivatives. Current Medicinal Chemistry-Anti-Cancer Agents, 2001; 1: 293-300.

Monks, A., Scudiero, D., Skehan, P., Shoemaker, R., Paull, K., Vistica, D., Hose, C., Langley, J., Cronise, P., Vaigro-Wolff, A., GrayGoodrich, M., Campbell, H., Mayo, J., Boyd, M. Feasibility of a HighFlux Anticancer Drug Screen Using a Diverse Panel of Cultured Human Tumor Cell Lines. Journal of the National Cancer Institute, 1991; 83: 757 766.

Orlikova, B., Schumacher, M., Juncker, T., Yan, C.C., InayatHussain, S.H., Hajjouli, S., Cerella, C., Dicato, M., Diederich, M. Styryllactone goniothalamin inhibits TNF-alpha-induced NF-kappaB activation. Food and chemical toxicology : an international journal published for the British Industrial Biological Research Association, 2013; 59: 572-578.

Petsophonsakul P., Pompimon W., Banjerdpongchai R. Apoptosis induction in human leukemic promyelocytic HL-60 and monocytic U937 cell lines by goniothalamin. Asian Pacific journal of cancer prevention: APJCP, 2013; 14: 2885-2889.

Seyed, M.A., Jantan, I., Bukhari, S.N.A. Emerging Anticancer Potentials of Goniothalamin and Its Molecular Mechanisms. BioMed Research International, 2014: 536508.
Sun, L., Zhao, R., Lan, X., Chen, R., Wang, S., Du, G. Goniolactone C, a styryl lactone derivative, inhibits PDGF-BB-induced vascular smooth muscle cell migration and proliferation via PDGFR/ERK signaling. Molecules, 2014; 19: 19501-19515.

Tian, Z., Chen, S., Zhang, Y., Huang, M., Shi, L., Huang, F., Fong, C., Yang, M., Xiao, P. The cytotoxicity of naturally occurring styryl lactones. Phytomedicine, 2006; 13: 181-186.

Tsai, I.-L., Lee, F.-P., Wu, C.-C., Duh, C.-Y., Ishikawa, T., Chen, J.-J., Chen, Y.-C., Seki, H., Chen, I.-S. New cytotoxic cyclobutanoid amides, a new furanoid lignan and anti-platelet aggregation constituents from Piper arborescens. Planta medica, 2005; 71: 535-542.

Vendramini-Costa, D.B., Monteiro, K.M., Iwamoto, L.H., Jorge, M.P., Tinti, S.V., Pilli, R.A., de Carvalho, J.E. Gastroprotective effects of goniothalamin against ethanol and indomethacin-induced gastric lesions in rats: Role of prostaglandins, nitric oxide and sulfhydryl compounds. Chemico-biological interactions, 2014; 224C, 206-212.

Wattanapiromsakul, C., Wangsintaweekul, B., Sangprapan, P., Itharat, A., Keawpradub, N. Goniothalamin, a cytotoxic compound, isolated from Goniothalamus macrophyllus (Blume) Hook. f. \& Thomson var. macrophyllus. Songklanakarin J. Sci. Technol, 2005; 27: 479-487.

Wiart, C. Goniothalamus species: a source of drugs for the treatment of cancers and bacterial infections? Evidence-based complementary and alternative medicine : eCAM, 2007; 4: 299-311.

\section{How to cite this article:}

Duc LV, Thanh TB, Thanh HN, Tien VN. Chemical constituents and cytotoxic effect from the barks of Goniothalamus chinensis Merr. \& Chun. growing in Vietnam. J App Pharm Sci, 2016; 6 (04): 001-005. 